\title{
Sensitivity Analysis of Swiftlet Farming in Kota Bangun, District Kutai Kartanegara Regency, Indonesia
}

\author{
Mursidah Mursidah ${ }^{1, *}$, Abubakar M. Lahjie ${ }^{2}$, Masjaya Masjaya ${ }^{3}$, and Yaya Rayadin ${ }^{2}$ \\ ${ }^{1}$ Faculty of Agriculture, Mulawarman University. Indonesia \\ ${ }^{2}$ Faculty of Forestry, Mulawarman University. Indonesia \\ ${ }^{3}$ Faculty of Social and Political Science, Mulawarman University. Indonesia \\ "Corresponding author. Email: mursidah.spmm@gmail.com
}

\begin{abstract}
farming is a high-risk business. However, given the level of income (as measured by financial viability), most swiftlet farmers take the risk. Swiftlet farming is a business that lasts for a long time. During this period there are several changes that occur, which will affect the viability of the business. These changes include costs, selling prices and production. This research aimed to analyze the sensitivity of swiftlet farming in Kota Bangun Subdistrict, East Kalimantan, Indonesia. This research used quantitative analysis method. Data were collected using purposive sampling to determine the location and sample of swiftlet houses, as well as in-depth interviews with respondents. The sensitivity analysis of Swiftlet farming was analyzed using the net Benefit-Cost Ratio (net B/C), Net Present Value (NPV), Internal Rate of Return (IRR) and Payback Period (PP) methods, assuming an increase in operating costs of $15 \%$ and a $30 \%$ reduction in benefits. The results showed that Swiftlet farming in Kota Bangun District is still financially feasible if there is an increased in operational costs by $15 \%$ or a decreased in benefits by $30 \%$, as well as an increased in operational costs and a decreased in benefits occured simultaneously.
\end{abstract}

Keywords: Benefit, Cost, Financial feasibility, Sensitivity analysis, Swiftlet

\section{INTRODUCTION}

The number of demands for swiftlet nests continues to increase and the prices are relatively high, resulting in more and more people who are interested in pursuing swiftlet farming. The traded swiftlet nests come from swiftlet houses and caves in the forest. Loot harvesting techniques that do not pay attention to sustainability make the swiftlet population less and less, so that the availability of swiftlet nests decreases, while demand increases. To answer this question, a swiftlet farming was carried out by making a swiftlet house [1]. Swiftlet farming by building swiftlet houses began to develop in Indonesia in the 1800s [2].

Each area where there is swiftlet cultivation has its own uniqueness, both geographically, Swiftlet population, food sources and micro environment, including whether the swiftlet cultivation area is manmade or natural habitat [3][5]. One of the islands that produce edible swiftlet nests is the island of Borneo [4]. There are two types of swiftlet houses on the island of
Borneo, made of concrete or wood. The cost of making a concrete swiftlet house is more expensive to build than a wooden building [6]. The area of the swiftlet house varies, depending on the area of land and the capital owned.

Consideration in choosing a business is the feasibility or benefits that will be obtained later. The market value or selling value of the swiftlet's nest is one of the determinants of the revenue to be obtained and the profits obtained. On the other hand, acceptance is also determined by the number of edible swiftlet nest produced. According to [6] land cover around the Swiftlet house affects the productivity of the swallow's nest produced from the Swiftlet's house, because land cover affects the availability of feed for the Swiftlet. In addition, a business that takes place in the long term, of course, cannot be separated from the business risks it faces. In the edible Swiftlet nest business, there are several changes that are feared to result in reduced profits, including an increase in operational costs if there is an effort to meet the Swiftlet's feed needs. 
Another change is the decrease in benefits due to lower selling prices. Because of these changes, it is necessary to carry out a sensitivity analysis.

This research aimed to analyze the sensitivity of swftlet farming in Kota Bangun District, Kutai Kartanegara Regency.

\section{MATERIALS AND METHODS}

This research was conducted in Kota Bangun District, Kutai Kartanegara Regency. The swiftlet house observed was chosen purposively, the selection was based on the building material of the swiftlet house (made of wood), already in production and the size of the swiftlet house (more than $400 \mathrm{~m}^{2}$ ). The research was conducted from June 2019 to December 2019.

Sensitivity analysis was carried out through financial feasibility assessment, which was analyzed using net benefit-cost ratio $(\mathrm{Net} B / \mathrm{C})$, net present value (NPV), internal rate of return (IRR) and payback period (PP) [712]:

\subsection{Net benefit-cost ratio (net $B / C)$}

Net $B / C$ is the ratio between the present value of positive net benefits and the present value of negative net benefits.

$$
N e t B / C=\frac{\sum_{t=1}^{n} N B t(+)}{\sum_{t=1}^{n} N B t(-)}
$$

(a business is feasible or profitable if Net $\mathrm{B} / \mathrm{C}>1$, not feasible if Net $\mathrm{B} / \mathrm{C}<1$, and the project is not profitable or loses if $\mathrm{Net} \mathrm{B} / \mathrm{C}=0$ ).

\subsection{Net Present Value (NPV)}

Net present value is the difference between the present value of the benefits and the present value of the costs.

$$
\mathrm{NPV}=\sum_{t=1}^{n} \frac{B t-C t}{(1+i)^{t}}
$$

Note :

$\mathrm{Bt}=$ benefit or gross profit in year $\mathrm{t}(\mathrm{Rp})$

$\mathrm{Ct}=$ cost in year $\mathrm{t}(\mathrm{Rp})$

$\mathrm{i}=$ discount factor $(\%)$

$\mathrm{n}=$ economic life of swiftlet house (years)

A business is feasible or profitable if NPV $>0$, not profitable or loss if NPV $<0$, and will return on capital or break even if NPV $=0$.

\subsection{Internal Rate of Return (IRR)}

The discount rate that can define a project's NPV as zero or the benefit-cost ratio equal to one is called the IRR.

$$
\mathrm{IRR}=i^{\prime}+\frac{N P V^{\prime}}{N P V^{\prime}+N P V^{\prime \prime}}\left(i^{\prime \prime}-i^{\prime}\right)
$$

Note :

$\mathrm{NPV}^{\prime}=$ positive NPV

NPV" = negative NPV

$\mathrm{i}^{\prime}=$ interest rate when NPV is positive

$\mathrm{i}^{\prime \prime}=$ interest rate when NPV is negative

A business is said to be feasible or profitable if IRR $>\mathrm{i}$, not feasible if IRR $<\mathrm{i}$, and if IRR = I it means break even, or neither profit nor loss.

\subsection{Payback Period (PP)}

Payback period is the time required to recover all costs incurred or the period required to return the invested capital using the yield or net cash flow.

$$
\mathrm{PP}=n+\frac{(a-b)}{(c-b)} \times 1 \text { years }
$$

Note :

$\mathrm{n}=$ the last year in which the cash flow was not able to cover the initial investment capital

$\mathrm{a}=$ amount of initial investment

$\mathrm{b}=$ cumulative cash flow for year $\mathrm{n}$

$\mathrm{c}=$ sum of accumulated cash flows for $\mathrm{n}+1$ years)

This project is feasible or profitable if $\mathrm{PP}<$ the economic life of the project, but the project is not feasible if PP > the economic life of the project, and the project is not profitable and does not lose money if PP is equal to the economic life of the project. project.

The assumption used in this sensitivity analysis is an increase in operational costs by $15 \%$ and a decrease in benefits by $30 \%$. The basis for determining the cost increase of $15 \%$ is the cost incurred if additional feeding is carried out. While the decrease in benefits if there is a decrease in the selling price.

\section{RESULTS AND DISCUSSION}

Changes in land cover will affect the availability of food for swiftlets. Swiftlet feed, which previously depended entirely on its availability in nature, will be supported by artificial feeding. Provision of artificial feed will certainly affect the costs incurred. The addition of artificial feed costs will certainly increase the total cost of swiftlet farming which in turn will affect the 
Table 1. Sensitivity Analysis of Swiftlet Farming

\begin{tabular}{|c|l|c|c|c|}
\hline $\begin{array}{c}\text { Busineess } \\
\text { Scale }\end{array}$ & \multicolumn{1}{|c|}{$\begin{array}{c}\text { Investment } \\
\text { Criteria }\end{array}$} & $\begin{array}{c}\text { Cost } \\
\text { Increased } \\
15 \%\end{array}$ & $\begin{array}{c}\text { Benefit } \\
\text { Decreased30 } \\
\%\end{array}$ & $\begin{array}{c}\text { Cost Increased 15\% and } \\
\text { Benefit Decreased 30\% }\end{array}$ \\
\hline \multirow{4}{*}{$512 \mathrm{~m} 2$} & Net B/C & 3.79 & 2.42 & 2.18 \\
\cline { 2 - 5 } & NPV & $1,300.58$ & 653.50 & 550.28 \\
\cline { 2 - 5 } & IRR & 29.61 & 26.15 & 25.04 \\
\cline { 2 - 5 } & PP & 5.68 & 7.54 & 8.20 \\
\hline \multirow{3}{*}{$800 \mathrm{~m} 2$} & Net B/C & 2.25 & 1.32 & 1.09 \\
\cline { 2 - 5 } & NPV & $1,051.38$ & 265.64 & 71.69 \\
\cline { 2 - 5 } & IRR & 24.02 & 16.43 & 12.11 \\
\cline { 2 - 5 } & PP & 10.48 & 15.79 & 19.73 \\
\hline \multirow{3}{*}{$1,600 \mathrm{~m} 2$} & Net B/C & 2.08 & 1.27 & 1.10 \\
\cline { 2 - 5 } & NPV & $1,534.51$ & 379.93 & 139.62 \\
\cline { 2 - 5 } & IRR & 23.19 & 15.75 & 12.47 \\
\cline { 2 - 5 } & PP (tahun) & 9.84 & 12.91 & 14.29 \\
\hline
\end{tabular}

assessment of the financial feasibility of the business. On the other hand, the conditions mentioned above can also cause a decrease in the amount of production.

Sensitivity assessment is carried out to determine the financial feasibility of Swiftlet nest business if the above changes occur. Assessment is carried out if there is a $15 \%$ increased in costs (due to an increased in input prices and additional feed) and a 30\% decreased in benefits (due to a decreased in selling prices and production).

\subsection{Cost Increased by $15 \%$}

If there is an increase in costs by $15 \%$, then the swiftlet house with a size of $512 \mathrm{~m}^{2} \mathrm{Net} \mathrm{B} / \mathrm{C}$ will decrease to 3.79 previously 4.06), the NPV will decrease by IDR 103.21 million to IDR $1,300.58$ million, the IRR will decrease from $30.00 \%$ to $29.61 \%$ and PP becomes longer to 5.68 years. To swiftlet house size of $800 \mathrm{~m}^{2}$, there was a decrease in Net B/C from 2.51 to 2.25 , NPV decreased to IDR $1,051.38$ million (previously IDR 1,245.33 million), IRR decreased by $1.11 \%$ from $25.13 \%$ to $24.02 \%$ and PP for 10.48 years (longer 1.64 years). Meanwhile, in the swiftlet house with a size of $1,600 \mathrm{~m}^{2}$, all investment criteria also decreased. Net B/C decreased to 2.08, NPV decreased from IDR $1,774.83$ million to IDR $1,534.51$, IRR to $23.19 \%$ and PP to 9.84 years.

\subsection{Benefits Decreased by $30 \%$}

In the $512 \mathrm{~m}^{2}$ swiftlet house, all investment criteria experienced a significant decline. Net B/C decreased from 4.06 to 2.42 , NPV decreased by $53.45 \%$ to IDR 653.50 million, IRR from $30.00 \%$ to $26.15 \%$ and PP
2.10 years longer to 7.54 years. For swiftlet house size of $800 \mathrm{~m}^{2}$, there was a decrease in Net B/C from 2.51 to 1.32, NPV decreased to IDR 265.64 million (previously IDR $1,245.33$ million), IRR decreased by $8.70 \%$ from $25.13 \%$ to $16.43 \%$ and PP for 15.79 years (longer 6.95 years). For swiftlet house size of $1,600 \mathrm{~m}^{2}$, Net B/C will decrease to 1.27 (previously 2.27), the NPV will decrease by IDR $1,394.90$ million to IDR 379.93 million, the IRR will decrease from $24.09 \%$ to 15.75 . \% and PP became slower to 12.91 years.

\subsection{Cost Increased by $15 \%$ and Benefits Decreased by $30 \%$}

For swiftlet house with a size of $512 \mathrm{~m}^{2}$, there was a decreased in Net B/C from 4.06 to 2.18 , NPV decreased to IDR 550.28 million (previously IDR 1,403.79 million), IRR decreased by $4.96 \%$ from $30.00 \%$ to $25.04 \%$ and PP for 8.20 years (longer 2.76 years). For swiftlet house size of $800 \mathrm{~m}^{2} \mathrm{Net} \mathrm{B} / \mathrm{C}$ will decrease to 1.09 (previously 2.51), the NPV will decrease by RP 1,173.64 million to RP 71.69 million, the IRR will decrease from $25.13 \%$ to $12.11 \%$ and PP became longer to 19.73 years. Likewise, for a swiftlet house with a size of $1,600 \mathrm{~m}^{2}$, all investment criteria experienced a significant decrease. Net B/C decreased from 2.27 to 1.10 , NPV decreased by $92.13 \%$ to IDR 139.62 million, IRR from $24.09 \%$ to $12.47 \%$ and PP 4.89 years longer to 14.29 years.

Based on the sensitivity analysis (Table 1), it can be seen that the swiftlet farming studied based on investment criteria is financially feasible, both when experiencing an increased in costs, a decreased in benefits, as well as an increase in costs and a decrease in 
benefits. Although the sensitivity analysis for both assumptions reduces the feasibility value of the swiftlet farming, the lower selling price results in a greater reduction in the value of financial viability. Although the sensitivity analysis for both assumptions reduces the feasibility value of the swiftlet farming, the lower selling price results in a greater reduction in the value of financial viability.

Sensitivity analysis was carried out with different assumptions by Sumardi et al. [13], namely production decreased by $30 \%$ and selling prices decreased by $20 \%$, with the results of this swiftlets farming being sensitive to changes in production, due to a significant decrease in the value of NPV, IRR and Net B/C. While the research of Yuniarti et al. [14], it was found that an increase in operational costs, an increase in benefits, and a decrease in benefits by $10 \%$ in Swiftlet farming indicate that this business is still feasible to be cultivated and developed.

As a business, of course the swiftlets farming also has risks that must be taken into account, including the lack of natural feed availability, so it is necessary to provide artificial feed, which will result in additional costs. On the other hand, high fluctuations in the selling price of swallow nests will have an impact on decreasing benefits. Based on the sensitivity analysis, all business scales still show that they are feasible to operate, even though their financial feasibility performance has decreased. To reduce the risk of decreasing the benefits obtained, it is necessary to make efforts to provide added value to swallow nests which have been marketed in the form of raw nests.

\section{CONCLUSION}

The increase in costs and the decrease in benefits resulted in a decrease in the performance of the investment criteria, although it was still financially feasible.

\section{ACKNOWLEDGMENTS}

The author would like to thank the respondents, Suparkat and family for their supports during the research in the field and anonymous reviewers for their constructive feedback to improve this manuscript.

\section{REFERENCES}

[1] R. Sankaran, The status and conservation of the edible-nest swiftlet (Collocalia fuchipaga) in the Andaman and Nicobar Islands. Biol Conserv vol. 97, 2001, pp. 283-294.

[2] A. Mardiastuti and T. Soehartono, Current situation of the edible-nest swiftlets in Indonesia : a revision. Technical Workshop and Conservation
Priorities and Actions Of The Sustainability of Harvesting and Trade in Nest of Swiftlets of The Genus Collocalia that Feature Prominently in the Bird-Nest Trade, Surabaya 4-7 November 1996.

[3] W. Saengkrajang, N. Matan, N. Matan, Nutritional composition of the farmed edible bird's nest (Collocalia fuchipaga) in Thailand. J Food Compos Anal vol. 31(1), 2013, pp. 41-45. DOI: 10.1016/j.jfca.2013.05.001.

[4] Q.H. Looi and A. R. Omar, Swiftlets and edible bird's nest industry in Asia. Pertanika J Scholarly Res Rev vol. 2(1), 2016, pp. 32-48.

[5] D. A. Zulkifli, R. Mansor, M. M. M. Ajat, F. Abas, A. Ideris, J. Abu, Differentiation of Malaysian farming and commercialized edible bird's nests through nutritional composition analysis. Pertanika J Trop Agric Sci vol. 42(3), 2019, pp. 871-881.

[6] Y. Ito, Y. Yamamoto, A. Usup, K. Matsumoto, A sustainable way of agricultural livelihood: Edible bird's nests in Indonesia, 2021, https: //www.researchsquare.com/article/rs-153977/v1.

[7] A. Arshad, Net present value is better than the internal rate of return, Interdisciplin $\mathrm{J}$ Contempro Bus vol. 4(8), 2012, pp. 211-219.

[8] S. Banerjee S, Contravention between NPV and IRR due to timing of cash flows: a case of capital budgeting decision of an oil refinery company. Am J Theoretical Appl Bus vol. 1(2), 2015, pp. 4852. DOI: $10.11648 /$ j.ajtab.20150102.13.

[9] M. Hopkinson, The case for project net present value (NPV) and NPV risk models. PM World J vol. 5 (6), 2016, pp. 2-9.

[10] K. Kunio and A. M. Lahjie, Agroforestry management with vanilla and agarwood in East Kalimantan. J Econ Sustain Dev vol. 6 (4), 2015, pp. 12-17.

[11] B. Setiawan, A. M. Lahjie, S. Yusuf, Y. Ruslim, Assessing the feasibility of forest plantation of sative species: A case study of Agathis dammara and Eusideroxylon zwageri in Balikpapan, East Kalimantan, Indonesia. Biodiversitas vol. 20 (9), 2019, pp. 2453-2461.

[12] Mursidah, A. M. Lahjie, Masjaya, Y. Rayadin, Y. Ruslim, The ecology, productivity and economy of swiftlet (Aerodramus fuciphagus) farming in Kota Bangun, East Kalimantan, Indonesia. Biodiversitas vol. 21(7), 2020, pp. 3117-3126. DOI: 10.13057 /biodiv/d210732 .

[13] D. Sumardi, Pordamantra, Sunariyo,Evaluationof the business feasibility of swiftlet nest in the 
Telaga Antang Subdistrict East Kotawaringin District. J-SEA vol. 13(2), 2018, pp. 51-58.

[14] V. Yuniarti, E. Yurisinthae, M. Maswadi, Financial feasibilty analysis of swiftlet bird nest business (Colacallia fuciphaga) in Matan Hilir Selatan District Ketapang Regency. Agribusiness J vol. 3(1), 2013, pp. 1-13. 